\title{
Causes and conditions of cross-national policy convergence
}

\author{
Katharina Holzinger and Christoph Knill
}

\begin{abstract}
It is the objective of this article to review the existing literature and to address theoretical deficits in the study of policy convergence. First, we briefly present the central indicators we apply for the assessment of policy convergence. In a second step, we identify and compare different causal mechanisms of crossnational policy convergence. Having elaborated on the major causes of policy convergence, however, we still know little about the conditions under which these factors actually lead to convergence. This is the central objective of the third part of our analysis, in which we develop theoretical expectations on different indicators of cross-national policy convergence.
\end{abstract}

KEY WORDS Europeanization; policy convergence; policy diffusion, policy transfer, public policy.

\section{INTRODUCTION}

The study of cross-national policy convergence is a highly popular research area in political science. While first studies date back to the early 1960 s, the academic popularity of the topic significantly increased during the 1990s. This development is closely related to an increasing research interest in the domestic impact of European integration and globalization. As a consequence, there is an ever-growing body of studies that investigate the occurrence and the underlying driving forces of cross-national policy convergence. Notwithstanding these enormous research efforts, it is generally acknowledged that we still have a limited understanding of the causes and conditions of policy convergence.

This deficit can be traced to two problems. First, as Seeliger (1996) argues, much more emphasis has been placed on the presentation of empirical results than on systematic theory-building. Second, policy convergence is a rather heterogeneous research field, with scholars coming from different academic backgrounds and disciplines (including, for instance, comparative politics, policy analysis and international relations). Hence, policy convergence is typically analysed from rather diverse theoretical perspectives employed in related 
research areas, such as policy transfer, policy diffusion or isomorphism. It is therefore hardly surprising that we find a broad number of different factors that are mentioned as potential causes of policy convergence. At the same time, theoretical and conceptual heterogeneity poses important restrictions on the comparability of the empirical findings gained in different convergence studies.

It is the objective of this article to review the existing literature and to address theoretical deficits in the study of policy convergence. We proceed in the following steps. First, we briefly present the central indicators we apply for the assessment of policy convergence. In a second step, we identify and compare different causal mechanisms of cross-national policy convergence. Having elaborated on the major causes of policy convergence, however, we still know little about the conditions under which these factors actually lead to convergence. This is the central objective of the third part of our analysis, in which we develop theoretical expectations on different indicators of cross-national policy convergence.

\section{HOW TO CONCEPTUALIZE POLICY CONVERGENCE?}

The definition of policy convergence as the growing similarity of policies over time still leaves a broad range of options as to how to empirically assess and evaluate similarity changes (Heichel et al. 2005). In so doing, we suggest various indicators, including not only the degree but also the scope and direction of convergence.

With respect to the degree of convergence, we first of all have to clarify the criteria on the basis of which we judge whether policies across countries are similar or not. In this context, a general distinction can be drawn between the similarity of policy outputs (the policies adopted by a government) and policy outcomes (the actual effects of a policy in terms of goal achievement). While studies on both dimensions can be found in the literature, we concentrate in the following analysis on policy outputs only. The governments are the agents reacting to problem pressure, experience gained elsewhere, pressure of powerful external actors, economic pressure, and legal obligation. Thus, governmental programmes are what count. Policy outcomes, by contrast, are only indirectly related to the causal mechanisms of convergence, because they are usually affected by many intervening variables. The adoption of a programme is a poor predictor of its implementation.

For the measurement of similarity change, we rely on the concept of $\sigma$-convergence. According to this concept, the degree of convergence increases with the extent to which the policies of different countries have become more similar to each other over time. Thus, convergence degree is the decrease of standard deviation from time $t_{1}$ to $t_{2}$.

The direction of convergence, by contrast, indicates the extent to which convergence coincides with an upward or downward shift of the mean from time $t_{1}$ to $t_{2}$. Convergence at the top or bottom presupposes therefore both a decrease of standard deviation and a shift of the mean (Botcheva and Martin 2001: 4). As 
shown in Table 1 , the comparison between the policies in time $t_{1}$ and $t_{2}$ for a number of countries can therefore yield highly different results.

The direction of convergence is usually related to the extent of state intervention or to the strictness of a regulation. Lax standards or laissez-faire policies are identified with the 'bottom', strict standards or interventionist policies with the 'top' (Drezner 2001: 59-64). The direction of convergence can only be measured whenever the policies under consideration come in degrees, which can be associated with a normative judgement on the quality of an intervention. Typical examples are the levels of environmental and consumer protection or labour standards. However, it is not always easy to identify what the top and the bottom are in a policy, because there may be different value judgements. For example, in media regulation there are competing goals of restricting harmful content, on the one hand, and freedom of information, on the other hand. Moreover, when policy instruments are compared it does not make much sense to speak of directions of convergence. Only in rare cases can a certain instrument be assumed to provide stricter (or less strict) regulation than another one. In many cases, it is therefore impossible to formulate hypotheses on the direction of convergence.

Although we are aware of the fact that countries might be exposed to several mechanisms of convergence (e.g. imposition or international harmonization) and that these mechanisms might interact (cf. Holzinger and Knill 2005), the following considerations are based on the analysis of the isolated effects of different mechanisms. Our primary interest is to theoretically investigate the effects and operation of single convergence mechanisms.

For the development of hypotheses on the degree and direction of convergence, only those subgroups of countries and policies that are of theoretical

Table 1 Potential configurations of convergence indicators

\begin{tabular}{|c|c|c|}
\hline Standard deviation & Regulatory mean & Interpretation \\
\hline \multirow[t]{2}{*}{ No change } & No change & $\begin{array}{l}\text { Persistence of diversity and level } \\
\text { of regulation }\end{array}$ \\
\hline & $\begin{array}{l}\text { Upward or downward } \\
\text { shift }\end{array}$ & $\begin{array}{l}\text { No convergence or divergence, } \\
\text { but common movement in the } \\
\text { same direction }\end{array}$ \\
\hline \multirow[t]{2}{*}{ Decrease } & No change & $\begin{array}{l}\text { Convergence, but persistence of } \\
\text { level of regulation }\end{array}$ \\
\hline & $\begin{array}{l}\text { Upward or downward } \\
\text { shift }\end{array}$ & Convergence at the top or bottom \\
\hline \multirow[t]{2}{*}{ Increase } & No change & $\begin{array}{l}\text { Divergence, but persistence of } \\
\text { level of regulation }\end{array}$ \\
\hline & $\begin{array}{l}\text { Upward or downward } \\
\text { shift }\end{array}$ & $\begin{array}{l}\text { Divergence, but common movement } \\
\text { in the same direction }\end{array}$ \\
\hline
\end{tabular}


interest can be expected to be actually affected by a certain mechanism of convergence. For example, if we talk about international harmonization, we would not expect any convergence effects on countries which are not members of the international institutions in which harmonization efforts take place. Hence, our statements about convergence degrees or directions are not related to all countries and policies under investigation, but only to the affected subgroups. It is important to emphasize that convergence within subgroups affected by a certain mechanism can, but need not, result in convergence for the whole sample of countries and policies under investigation.

To grasp potential effects of certain mechanisms on all countries and policies under investigation, we rely on a further indicator, namely the scope of convergence. The scope of convergence increases with the number of countries and policies that are actually affected by a certain convergence mechanism, with the reference point being the total number of countries and policies under study. There is no straightforward relationship between degree and scope of convergence. Although it might often be the case that an increase in the number of converging countries actually reduces the variation among all countries, there are conceivable constellations in which even the opposite might be the case. For example, a subgroup of countries might converge towards a point far away from the other countries.

\section{WHAT CAUSES POLICY CONVERGENCE?}

As policy convergence is a theoretically rather heterogeneous field of research, it is hardly surprising that the literature offers many factors that might lead to

Table 2 Indicators of policy convergence

\begin{tabular}{|c|c|c|c|}
\hline Indicator & Research question & Reference point & Operationalization \\
\hline $\begin{array}{l}\text { Degree of } \\
\text { convergence }\end{array}$ & $\begin{array}{l}\text { How much } \\
\text { similarity } \\
\text { increase } \\
\text { over time? }\end{array}$ & $\begin{array}{l}\text { Subgroup of } \\
\text { countries and } \\
\text { policies affected } \\
\text { by a certain } \\
\text { mechanism }\end{array}$ & $\begin{array}{c}\text { Decrease in } \\
\text { standard } \\
\text { deviation } \\
\text { over time }\end{array}$ \\
\hline $\begin{array}{l}\text { Convergence } \\
\text { direction }\end{array}$ & $\begin{array}{l}\text { In what direction } \\
\text { (upward or } \\
\text { downward } \\
\text { shift of the } \\
\text { regulatory mean)? }\end{array}$ & $\begin{array}{l}\text { Subgroup of } \\
\text { countries and } \\
\text { policies affected } \\
\text { by a certain } \\
\text { mechanism }\end{array}$ & Mean change \\
\hline $\begin{array}{l}\text { Convergence } \\
\text { scope }\end{array}$ & $\begin{array}{l}\text { How many and } \\
\text { which countries } \\
\text { and policies } \\
\text { are converging? }\end{array}$ & $\begin{array}{l}\text { All countries } \\
\text { and policies } \\
\text { under } \\
\text { investigation }\end{array}$ & $\begin{array}{l}\text { Number of } \\
\text { countries } \\
\text { and policies }\end{array}$ \\
\hline
\end{tabular}


cross-national convergence. Moreover, suggestions on causal factors can not only be found in studies explicitly concerned with policy convergence, but also in the literature on policy transfer, diffusion and isomorphism which is closely related to the study of convergence. Transfer and diffusion are processes that might result in convergence. Thus, the factors triggering these processes can be interpreted as potential causes of convergence. The same holds true for the mechanisms driving isomorphism - a concept that differs from convergence only with respect to its empirical focus on organizational structures (Knill 2005).

Although there is considerable overlap, the causal factors enumerated vary. Some authors provide lists of mechanisms, while others provide classifications. For example, Hoberg (2001) lists parallel domestic problem pressures, emulation, international legal constraints, and international economic integration as potential factors driving convergence. Bennett (1991) mentions convergence through emulation, élite networking, harmonization, and penetration. Simmons and Elkins (2004) distinguish three diffusion mechanisms: direct economic competition, informational networks, and social emulation. In DiMaggio and Powell's (1991) theory, institutional isomorphism can result from coercion, mimetic processes, and normative pressures.

Dolowitz and Marsh $(1996,2000)$ provide a classification along a continuum between coercive and voluntary policy transfer, ranging from perfectly rational lesson-drawing of government A learning from government B to the direct imposition of a policy on country A by country B. However, it is difficult to draw the distinction between coercive and voluntary transfer. Transfer as a result of regulatory competition, for example, is classified as direct coercion (1996: 348), while 'the desire for international acceptance' is classified as 'voluntarily but driven by perceived necessity' (2000: 13). In both cases, national governments may respond to external pressures; however, they are not 'forced' to do so. On the other side of the continuum, can there ever be perfect 'voluntariness', in the sense that there is no pressure or no incentive to react to some challenge? Even lesson-drawing implies that a government feels the need to learn. It is unclear where voluntariness ends and where coercion begins.

In the following we present a list of the potential causes of policy convergence discussed in the literature. This list is based on the analytical distinction of five causal mechanisms of policy convergence: imposition, international harmonization, regulatory competition, transnational communication and independent problem-solving. The hypotheses about policy convergence we will formulate in section 4 are based on the distinction of these mechanisms. As summarized in Table 3 below, each mechanism combines a stimulus and a corresponding response, i.e. the behaviour actually leading to convergence. The causal mechanism leads to convergence, if the response actually occurs.

\section{Imposition}

The mechanism of imposition is described in the literature under many names. For DiMaggio and Powell, 'coercive isomorphism results from both formal and 
Table 3 Mechanisms of policy convergence

\begin{tabular}{lll}
\hline Mechanism & \multicolumn{1}{c}{ Stimulus } & \multicolumn{1}{c}{ Response } \\
\hline Imposition & $\begin{array}{c}\text { Political demand } \\
\text { or pressure }\end{array}$ & Submission \\
$\begin{array}{l}\text { International } \\
\text { harmonization }\end{array}$ & $\begin{array}{c}\text { Legal obligation } \\
\text { through international law }\end{array}$ & Compliance \\
$\begin{array}{l}\text { Regulatory } \\
\text { competition }\end{array}$ & Competitive pressure & Mutual adjustment \\
$\begin{array}{l}\text { Transnational } \\
\text { communication }\end{array}$ & & \\
$\begin{array}{l}\text { Lesson-drawing } \\
\begin{array}{l}\text { Transnational } \\
\text { problem-solving }\end{array}\end{array}$ & Problem pressure & \\
$\begin{array}{l}\text { Emulation } \\
\begin{array}{l}\text { International } \\
\text { policy promotion }\end{array}\end{array}$ & Desire for conformity & $\begin{array}{c}\text { Transfer of model } \\
\text { found elsewhere }\end{array}$ \\
$\begin{array}{l}\text { Independent } \\
\text { problem-solving }\end{array}$ & Parallel problem pressure & $\begin{array}{c}\text { Adoption of commonly } \\
\text { developed model }\end{array}$ \\
\hline
\end{tabular}

informal pressures exerted on organizations by other organizations upon which they are dependent' (1991: 67). Dependent organizations are likely to adopt patterns of behaviour sanctioned by organizations that control critical resources (Guler et al. 2002: 212). Resources are used as an incentive or penalty. Similar to DiMaggio and Powell (1991), Guler et al. refer to organizations within the state rather than to states. Nevertheless, their definition of coercive isomorphism as 'homogeneity pressures stemming from political influence' (2002: 212) is closely related to our understanding of convergence through imposition.

Resource dependence also plays a role in the definition of imposition of policies by Meseguer Yebra (2003). She deals with the stabilization policies and adjustments of economies which many governments have introduced under the pressure of international financial institutions. In this field, the mechanism of imposition is epitomized by conditionality. The latter implies exchanging policies for loans. A quantitative empirical analysis leads Meseguer Yebra to the conclusion that governments, pressed by international financial institutions, in fact switched to liberal trade regimes.

Dolowitz and Marsh (1996: 347) treat convergence through imposition under the heading of 'direct coercive transfer'. They differentiate between two mechanisms, which they call 'direct imposition', and 'conditionality' (Dolowitz and Marsh 2000: 9). They speak of direct imposition when 'one government forces another to adopt a policy'. While direct imposition of policies on one 
country by another is rare, supranational institutions often play an important role in coercive policy transfer. They use the example of the spread of Western monetary policies to Third World countries. This spread was driven by conditionalities that accompanied loans given by the World Bank or the International Monetary Fund.

According to Bennett 'convergence by penetration' arises when states are forced to conform to actions taken elsewhere by external actors (1991: 227). His main examples are multinational businesses that exert pressure on governments to harmonize policies concerning products (1991: 228). However, as multinational firms can surely not force governments and as they have no political power, we subsume this kind of pressure for international co-operation under convergence through regulatory competition. Another example are voluntary international agreements, for instance at the level of the Organization for Economic Co-operation and Development (OECD) and the Council of Europe (Bennett 1991: 228). In our view, this falls under the mechanism of transnational communication (promotion of policy models) rather than reflecting convergence through imposition.

Tews identifies two conditions for 'forced policy transfer' (2002: 1181f.): first, the relations of the political units involved are characterized by structural asymmetry of power. Second, the new policy has been pushed through against the will of the legitimized politicians in the political unit forced to adopt the policy. The second condition seems to be overly restrictive. A policy imposed on a country by an international institution may not be at the top of the preference list of the national government, but it may nevertheless not be against its will; sometimes the 'imposition' may even help a democratic government to introduce a policy not favoured by its citizens.

In our definition, convergence through imposition occurs whenever an external political actor forces a government to adopt a certain policy. This presupposes asymmetry of power. Often, there is an exchange of economic resources for the adoption of the policy. There are two typical cases: the unilateral imposition of a policy on a country by another country, and the conditionality by an international institution. The first case might, for example, occur after a war. It will be rare and does not lead to far-reaching convergence, as it will hardly involve many countries. The second case is more prevalent and usually involves a greater number of countries. Moreover, the policies which form the content of the conditionality - typically economic policies or human rights - are usually already applied in wider parts of the international community.

\section{International harmonization}

The mechanism of international harmonization leads to cross-national convergence if the involved countries comply with uniform legal obligations defined in international or supranational law. Harmonization refers to a specific outcome of international co-operation, namely to constellations in which national 
governments are legally required to adopt similar policies and programmes as part of their obligations as members of international institutions.

International harmonization and more generally international co-operation presuppose the existence of interdependencies or externalities which push governments to resolve common problems through co-operation within international institutions, hence sacrificing some independence for the good of the community (Drezner 2001: 60; Hoberg 2001: 127). Once established, institutional arrangements will constrain and shape the domestic policy choices, even as they are constantly challenged and reformed by their member states. This way, international institutions are not only the object of state choice, but at the same time consequential for subsequent governmental activities (Martin and Simmons 1998: 743). However, as member states voluntarily engage in international co-operation and actively influence corresponding decisions and arrangements, the impact of international harmonization on national policies constitutes no hierarchical process; it can rather be interpreted as 'negotiated transfer' (Dolowitz and Marsh 2000: 15).

\section{Regulatory competition}

While the mechanism of international harmonization is based on domestic compliance with legal obligations, regulatory competition is expected to lead to cross-national convergence, as countries facing competitive pressure mutually adjust their policies. Regulatory competition presupposes economic integration among countries. Especially with the increasing integration of European and global markets and the abolition of national trade barriers, the international mobility of goods, workers and capital puts competitive pressure on the nation states to redesign domestic market regulations in order to avoid regulatory burdens restricting the competitiveness of domestic industries. The pressure arises from (potential) threats of economic actors to shift their activities elsewhere, inducing governments to lower their regulatory standards. This way, regulatory competition among governments may lead to a race to the bottom in policies, implying policy convergence (Hoberg 2001: 127; Simmons and Elkins 2004; Drezner 2001: 57-9). Theoretical work, however, suggests that there are a number of conditions that may drive policy in both directions (Vogel 1995; Scharpf 1997; Kern et al. 2000; Holzinger 2002, 2003), including, for example, the type of policy concerned (product or process standards), or the presence of interests other than business in national politics.

\section{Transnational communication}

Under the term of transnational communication we summarize a number of different but related mechanisms, including lesson-drawing, transnational problem-solving, emulation and the transnational promotion of policy models. In contrast to the other mechanisms discussed so far, they have in common that their operation is purely based on communication among 
countries. The other mechanisms presuppose either political pressure (imposition), legal obligation (harmonization), competitive pressure (regulatory competition) or parallel problem pressure (independent problem-solving). Communication might also play a role in these cases; however, it is not the main factor accounting for convergence effects. So far, in the literature no established heading for these different, but closely related mechanisms exists. One could certainly argue that each of the mechanisms summarized under transnational communication can be considered as a mechanism in its own right. However, they share an important characteristic that crucially distinguishes them from all other causal mechanisms, namely, they presuppose nothing but information exchange and communication with other countries. Moreover, the theoretical expectations with regard to their convergence effects are rather similar.

\section{Lesson-drawing}

The mechanism of lesson-drawing refers to constellations of policy transfer in which governments rationally utilize available experience elsewhere in order to solve domestic problems. According to Rose, who introduced the concept, lesson-drawing is based on a voluntaristic process whereby government $\mathrm{A}$ learns from government B's solution to a common problem what to do ('positive lessons') or what not to do ('negative lessons'). The government is modelled as a rational actor who poses the question: 'Under what circumstances and to what extent would a programme now in effect elsewhere also work here?' (Rose 1991: 4). The creation of new programmes, however, need not be based on the mere copying of other policies, but can take many different forms, reaching from hybrids of transferred and domestically developed components to completely new models. Rose also emphasizes that drawing a lesson does not require policy change: a programme elsewhere may be evaluated negatively or there may be no way to transfer it (1991: 22). Therefore, lesson-drawing is not the same as policy convergence.

A closely related concept is presented by Meseguer Yebra (2003) who applies the concept of Bayesian learning to policy learning. Bayesian learning is a mode of rational, experience-based learning. Governments are modelled as perfectly rational learners. They update their beliefs on the consequences of policies with all available information about policy outcomes in the past and elsewhere. They choose the policy that is expected to yield the best results. Bayesian learning is a formal mechanism, but the notion of learning in this concept is very similar to Rose's concept of lesson-drawing. However, in Meseguer Yebra's approach, governments will converge in their policy choices if they are exposed to the same information. This implies that there is a 'best solution' - given a certain state of information. Only if governments are not perfectly rational and do not collect all available information may divergence occur.

\section{Transnational problem-solving}

Similar to lesson-drawing, transnational problem-solving assumes processes of rational learning. In the latter case, however, convergence is not the result of 
bilateral transfer. Rather, it is driven by the joint development of common problem perceptions and solutions to similar domestic problems and their subsequent adoption at the domestic level. Transnational problem-solving typically occurs within transnational élite networks or epistemic communities, defined as networks of policy experts who share common principled beliefs over ends, causal beliefs over means and common standards of accruing and testing new knowledge (Haas 1992: 3). Common educational and normative backgrounds typically facilitate joint development of common policy models in such constellations (DiMaggio and Powell 1991: 73).

It is well conceivable that transnational problem-solving in élite networks can prepare the ground for subsequent activities of international harmonization. This holds true especially for problems characterized by strong interdependencies. At the same time, however, it is emphasized that international institutions play an important role in forging and promulgating transnational epistemic communities (Simmons and Elkins 2004). In other words, regular negotiations and discussions on problems subject to harmonization provide the ground for joint problem-solving in related areas that do not necessarily require a joint solution through international law. This argument is supported by the findings of Kern (2000: 144) who shows that international institutions play an important role in accelerating and facilitating cross-national policy transfer. They constitute important channels for multilateral communication and policy diffusion. Kern shows that - compared to policy exchange resting on bilateral and horizontal communication between countries - policy models spread much broader and faster if these countries are members of the same international institution.

\section{Emulation of policies}

Policy convergence through emulation is driven by the mere desire for conformity with other countries rather than the search for effective solutions to given problems. Consequently, emulation usually implies the simple copying of policies adopted elsewhere. Which factors account for this search for conformity? In the literature, various aspects are mentioned.

First, it is argued that emulation is a function of the number of countries that have already adopted a certain policy. As argued in herding theories, it can be optimal for a country to follow the behaviour of others even without using further information than the sheer number of followers. The fact that many others apply a certain policy serves as information that this might be the best thing to do (Levi-Faur 2002). In theories of population ecology, a different rationale is emphasized: emulation is the result of the socially embedded behaviour of actors (Meyer and Rowan 1977; Baum and Oliver 1992). The most widespread solution to a problem becomes the obvious way of dealing with it whereas other possible solutions are no longer considered.

Second, emulation can be driven by the striving of organizations to increase their social legitimacy by embracing forms and practices that are valued within the broader social and institutional environment (DiMaggio and Powell 1991: 
70). States might sometimes copy mimetically the policies of other states simply to legitimate conclusions already reached (Bennett 1991: 223).

Third, a psychologically based rationale for emulation is the desire of actors 'not to be left behind', a mechanism that has been transferred to the behaviour of state actors within the international system (Meyer et al. 1997; Finnemore 1996; Tews 2002). In the theory of DiMaggio and Powell 'mimetic isomorphism' occurs especially when an innovation is poorly understood and when its consequences are still unclear (1991: 69). The fear of not being left behind might be a result of uncertainty, but might also be a motive in itself.

Fourth, there are rational motivations. Bennett observes that emulation might be a consequence of time pressures: 'the more urgency that is perceived, the more likely will be the imitation of solutions without lengthy analysis and investigation' (1991: 223). Finally, compared with more demanding forms of learning, the costs of information are probably much lower for simple imitation (Tews 2002: 180).

\section{International policy promotion}

Countries might not only be inspired to adopt a certain policy because of rational learning or their desire for conformity. They can also be motivated to do so because of legitimacy pressures emerging from the promotion of policy models by international institutions. In contrast to the mechanism of transnational problem-solving, policy convergence is not the result of joint problem-solving efforts of countries represented in transnational networks, but is driven by the active role of international institutions that are promoting the spread of distinctive policy approaches they consider particularly promising.

Cross-national policy transfer is stimulated by non-binding international agreements or propositions on broad goals and standards that national policies should aim to achieve, institutionalized peer review and identification of best practice (benchmarking) as well as the construction of league tables ranking national policies in terms of performance to previously agreed criteria (Humphreys 2002: 54; Tews 2002: 174). International institutions, such as the European Union (EU), the OECD or the World Bank, but also nongovernmental organizations (NGOs) and transnational interest organizations (Keck and Sikkink 1998), play a highly active role in this process. In constantly searching for new policy ideas, disseminating best practice and evaluating domestic policy performance, they function as mediators of cross-national policy transfer, urging national governments to adopt successful policy models (Kern et al. 2000: 10). Countries that deviate from recommended policy models or rank low in international league tables face pressure to legitimate their policy approaches in light of 'international scrutiny'.

In many instances, promotion activities by international institutions originate from the activities of individual states seeking to convince other countries to copy their policy models. Countries which have developed innovative policy concepts generally have a strong interest in establishing their approach as an 
international solution in order to minimize the costs of institutional and economic adjustment to potentially diverging internationally promoted policy models. This pattern of leaders using international institutions as leverage when trying to drag along the laggards has not only been observed in the EU (Héritier et al. 1996; Andersen and Liefferink 1997), but also at the level of the OECD and other international institutions (Jänicke 1998: 334; Wallace 1995: 267).

\section{Independent problem-solving}

Many authors observe that convergence of policies between several countries can arise as a result of similar but independent responses of political actors to parallel problem pressures. Just as individuals open their umbrellas simultaneously during a rainstorm, governments may decide to change their policies in the presence of tax evasion, environmental pressures, such as air pollution, or an ageing population. This causal mechanism has been discussed under the names of functional, technocratic or technological determinism (Rose 1991: 9; Bennett 1988: 417), clustering (Simmons and Elkins 2004), spurious diffusion (Gilardi 2005; Gilardi and Braun 2005), or parallel domestic pressures (Hoberg 2001: 127).

Similar responses to parallel problem pressure are not the same as policy transfer or diffusion, since under this mechanism actors do not behave in response to each other's actions (Gilardi 2005). Rather, independent problem-solving presupposes that there is no communication between countries; i.e. they are not informed about the other countries' policy choices. As Bennett notes, the analyst of policy convergence 'must avoid the pitfall of inferring from transnational similarity of public policy that a transnational explanation must be at work' (1991: 231).

\section{WHEN DOES POLICY CONVERGENCE OCCUR?}

Having identified the causal mechanisms of policy convergence, it is the objective of this section to develop theoretical expectations about the conditions of their operation. We aim at further specifying the mechanisms in order to develop testable hypotheses with respect to degree, direction, and scope of cross-national policy convergence for each mechanism. To answer these questions, a point of reference is needed. As a reference point, we assume a situation where no mechanism is at work and where the policies of the countries under consideration are characterized by diversity.

\section{Imposition}

As a matter of fact, imposition implies that the country forced to adopt a certain model has not much choice in modifying the policy. As a consequence, imposition can generally be expected to lead to complete similarity of the policies of the submitting country and the policies of the imposing country or institution. 
While imposition hence results in a high degree of convergence, the scope of convergence is affected by the number of countries required to change their policies.

In this context, we have to distinguish between imposition by individual countries and imposition by international institutions. In the first case of unilateral imposition, usually only a few states might be affected; i.e. convergence occurs only among a small number of countries. The scope of convergence is much higher, by contrast, if imposition takes place through international institutions. Convergence will occur not only among all countries that similarly depend on the international institutions enacting the conditionality, but also among the dependent countries and the member states of the international institutions enacting the conditionality, if those members wish to export a policy which they also apply at home.

With respect to the impact of imposition on the direction of convergence, the extent to which imposition coincides with a shift of the regulatory mean depends on the level of regulation or intervention that is prescribed by the imposing country or institution. There is empirical evidence that imposition through international institutions has led to convergence at the top. This holds true especially in cases where conditionality requires compliance with certain standards in fields such as human rights, environmental protection, data protection, accounting or financial risks. In trade liberalization or privatization, by contrast, imposition implies a lower level of intervention - which is in these fields valued higher by the international community than interventionist policies. Hence, in this case, we can only identify shifts in the regulatory mean, while any judgement about whether this shift can be interpreted as upward or downward does not make much sense.

\section{International harmonization}

The scope of cross-national convergence triggered by international harmonization is affected by two factors. First, as convergence effects are restricted to those countries that are actually committed to international agreements or supranational regulations, the scope of convergence through harmonization increases with the number of countries that are members of the international institution or regime with the power to enact legally binding rules. Second, the number of policies affected through harmonization increases with the number of areas covered by the legislation of the international organization in question.

With regard to the extent to which international harmonization triggers cross-national convergence, two factors can be identified. First, the degree of convergence varies with the legal specification of international law. Specification is particularly high if international law requires the total or minimum harmonization of national standards. Convergence effects are less pronounced, by contrast, if legal rules are defined in a less rigid way, leaving member states broad leeway for selecting appropriate instruments to comply with international policy objectives. In this respect, varying discretion levels are conceivable, 
reaching from differentiated regulatory requirements, the prescription of broad objectives rather than detailed substantive or procedural regulations to mutual recognition and opting-out clauses.

Second, the degree of similarity will increase with the extent to which compliance with legal obligation can actually be enforced. International institutions reveal important differences in terms of their enforcement powers. The EU can be characterized as an institution in which such powers are comparatively well developed, given the direct effect and the supremacy of European law, the influential role of the European Court of Justice in the enforcement of Community law, the - albeit restricted - monitoring activities of the European Commission as well as the opportunity to financially sanction non-compliant member states. Against this background, the converging effects of European legislation can be expected to be higher than those of intergovernmental organizations or international regimes, where enforcement powers are less developed.

To what extent does convergence through international harmonization coincide with upward or downward shifts of the regulatory mean? The answer to this question basically depends on factors such as decision rules, interest constellations and the distribution of power between the involved actors (typically national governments and international organizations) which shape the negotiations at the level of international institutions. As the constellation of these factors might vary from case to case, in principle, every result within the span of regulations preferred by the involved national governments is possible. Notwithstanding this openness, the theoretical modelling generally predicts an outcome which reflects a compromise, hence lying somewhere in the middle between countries favouring extreme positions of either rather strict or weak regulations, with a strong tilt towards the preferences of the more powerful states (Drezner 2001: 61; for the EU: Holzinger 1994: 465-8; Tsebelis 2002: ch. 11).

However, even if we assume that the final agreement reflects a compromise between high-regulating and low-regulating countries, we still need to know whether and in which direction the mean of national regulatory levels will change as a result of this compromise. For this purpose, it is useful to distinguish between total and minimum harmonization. ${ }^{1}$

In the case of total harmonization, the expected result is that convergence coincides with no or only minimal mean changes of regulatory levels. Assuming that the international agreement on average lies in the middle between the levels of high-regulating and low-regulating countries, it can be expected that the required upward and downward moves of national standards will neutralize each other, hence implying no significant departure from the status quo.

The constellation looks different, however, if international rules are directed at minimum rather than total harmonization of national regulations. In this case, it is still possible for countries with a preference for higher regulatory levels to enact standards beyond the minimum level specified in international agreements. While deviations to the top are therefore still possible, countries with lower standards are obliged to raise their standards levels at least to the 
international minimum level. We thus predict that minimum harmonization is more likely to result in shifting the regulatory mean upward, as is the case with total harmonization. This expectation rests on two assumptions. First, the international minimum standard reflects a compromise between high-regulating and low-regulating countries. Second, not all high-regulating countries will lower their standards towards the minimum level.

\section{Regulatory competition}

A number of conditions can be derived from theories of regulatory competition (Vogel 1995; Scharpf 1997; Holzinger 2003) which affect our convergence indicators. To begin with, these theories point to various factors that restrict the scope of potentially converging countries and policies. On the one hand, potential convergence effects of regulatory competition presuppose economic integration between market economies. Even in constellations of high economic integration, no competitive pressures will emerge in and between non-market economies. This scenario applies in particular to the communist countries before 1990. On the other hand, a qualification applies to the policies for which convergence effects are predicted. Adjustments will be most pronounced for trade-related policies, such as product or process standards. No convergence is expected for policies, which are subject to low competitive pressures from international markets. This holds true for all policies that are not directly related to products or to production processes, such as nature or bird protection policies. It also holds true where trade-related policies are concerned, but the effects of the regulation on production costs are low. In this case they do not affect competition between industries in different countries.

In general, theories of regulatory competition predict that countries adjust policy instruments and regulatory standards in order to cope with competitive pressures emerging from international economic integration. The more exposed a country is to competitive pressures following on from high economic integration (emerging from its dependence on the trade of goods, capital and services with other countries), the more likely it is that its policies will converge with other states with international exposure. In other words, the degree of convergence depends on the level of competitive pressures to which countries are exposed.

There is an ongoing debate in the literature on the direction of convergence caused by regulatory competition. Often a distinction is made between product and production process standards (Scharpf 1997; Holzinger 2003). In the case of process standards, we find a widely shared expectation that policy convergence will occur at the lowest common denominator; states will gravitate towards the policies of the most laissez-faire country (Drezner 2001). If the regulation of production processes implies an increase in the costs of production, potentially endangering the international competitiveness of an industry, regulatory competition will generally exert downward pressures on economic regulations (Scharpf 1997: 524). It is assumed that governments 
are ready to lower environmental standards in the face of lobbying and exit threats exerted by the respective industry.

Expectations are less homogeneous for product standards. While industries in both low-regulating and high-regulating countries have a common interest in harmonization of product standards to avoid market segmentation, the level of harmonization can hardly be predicted without the examination of additional factors. Most important in this context is the extent to which high-regulating countries are able to factually enforce stricter standards. If it is possible to erect exceptional trade barriers, as, for example, for health or environmental reasons under EU and World Trade Organization (WTO) rules, convergence at a high level of regulation is to be expected (Scharpf 1997; Vogel 1995). If such exceptional trade barriers cannot be justified, by contrast, competitive pressure will induce governments to lower their standards (Holzinger 2003: 196).

\section{Transnational communication}

With respect to the number of countries and policies potentially affected by transnational communication, only a few restrictions apply, given the rather undemanding precondition of information about policy choices of other countries. It is therefore impossible to identify factors that restrict the scope of convergence through transnational communication for certain policies or countries.

The fact that transnational communication might potentially affect all countries and policies under investigation does not imply, however, that this mechanism produces cross-national policy convergence in each constellation. Rather, its operation varies with several factors. First, research on emulation emphasizes that the probability of adoption increases with the number of countries that have already switched to a certain policy model. In other words, the degree of existing policy similarity across countries crucially affects the likelihood of future similarity changes through emulation.

Second, as argued in the literature on lesson-drawing, the degree of convergence varies with the extent to which policy transfer occurs between countries with strong cultural linkages. In their search for relevant policy models, decision-makers are expected to look at the experiences of those countries with which they share an especially close set of cultural ties (Strang and Meyer 1993). Especially in constellations characterized by high uncertainty about the consequences of policy choices, decision-makers are likely to imitate the practices of nations with which they share linguistic, religious, historical or other cultural linkages (Friedkin 1993; Simmons and Elkins 2004).

Third, the adoption of similar policies across countries varies with the compatibility of transnational concepts and domestic policy legacies. The degree of expected convergence will decrease with the cost of adaptation implied by the adoption of the policy concept in question (Kern et al. 2000; Knill 2001). If, for instance, the adoption of a certain model requires far-reaching changes in existing institutional arrangements (regulatory frameworks, administrative 
structures), there is a high probability for only partial or even refused transfer. The same scenario applies to constellations in which the model adoption entails high economic costs or is likely to face strong political opposition (e.g. in the case of strong redistributive effects among national actor coalitions). As a consequence of these considerations, we can expect the degree of convergence to vary with two conditions: first, convergence depends on the specification of the model to be adopted. The broader its definition, the lower are potential costs of adjustment, given the high discretion for domestic application. Second, convergence will be higher among states that share similar policy legacies (e.g. welfare state traditions) and therefore face lower costs of adjustment when borrowing policy models from each other. This means that transnational communication will have stronger convergence effects among states that are already relatively similar in terms of existing institutional structures than among states that are characterized by highly different arrangements.

Fourth, as information and knowledge exchange between states is the essential requirement for most transnational communication mechanisms becoming effective (Simmons and Elkins 2004), the degree of convergence will be particularly high among those countries that are strongly interlinked in varying transnational networks. Of particular importance in this respect is common membership in international institutions that play an important role in increasing the interaction density between their members, hence intensifying transnational information exchange (Kern 2000: 267).

To what extent does convergence through transnational communication lead to shifts in the level of domestic regulations? General statements to answer this question are hardly possible. This holds true in particular for the mechanisms of lesson-drawing, transnational problem-solving and emulation. The fact that states adopt a certain innovation or copy policy concepts successfully applied in other countries does not automatically imply that this results in an increase in regulatory levels. It might well be the case that states adopt less demanding regulations, following corresponding patterns in other countries (e.g. replacing of interventionist regulation by self-regulation).

The only mechanism that allows for more precise predictions refers to the promotion of policy models. This holds true in particular where promotion is based on the dissemination and evaluation of best practice. This competition of ideas can generally be expected to result in an overall strengthening of regulatory concepts. Since international organizations will in general promote the most progressive national approach, benchmarks will be set at the level of the highest-regulating country. Hence, an upward shift of the mean will be the likely result.

\section{Independent problem-solving}

Bennett identifies two conditions for parallel problem pressure to lead to the same solution (1988: 419): first, there must be certain intrinsic characteristics of a problem that would inevitably lead to its similar treatment. Second, 
these characteristics must be universally recognized. The problem with this argument is, however, that the extent to which convergence might be observed is strongly dependent on the definition of 'similar treatment'.

If similarity is defined in a very demanding way, including, for instance, the choice of instruments and regulatory settings, there will rarely be only one solution to a problem (Rose 1991: 9; Hoberg 1991). This is already valid for a relatively simple problem, such as the rainstorm mentioned above. Although many people may open their umbrellas, others may put on a hat or seek shelter. This is a problem where we already have something like 'one best solution', namely the umbrella.

If we apply a less demanding definition of similarity, by contrast, there is a higher probability that we observe convergence as a result of parallel problem pressure. For example, if the problem is that it starts raining, and the similar solution' is that people react to it, we will probably find convergence, as most people will in fact react somehow. Or, if the problem is the ageing of society, and the solution is that the pension schemes are changed, we might also find convergence, as most governments will change pension schemes. This still implies, however, a comparatively low degree of convergence, as the new pension schemes may be very different.

As the bandwidth of possible solutions or reactions to a problem is usually very broad, in the case of parallel problem pressure convergence can be expected only in very general terms (in the sense of mere reaction). A higher degree of convergence can be expected only if some additional conditions are fulfilled; for example, if the cultural, institutional or socio-economic similarity of the affected countries is high. In other words, countries that share a broad number of characteristics are more inclined to react independently to a problem in a similar way.

While structural similarity may thus affect the degree of convergence among countries reacting to parallel problem pressures, it is impossible to develop statements about potential convergence directions. We cannot predict whether parallel problem pressure leads to convergence at a high or low level of regulation or intervention.

\section{CONCLUSION}

In this article, we analysed various causes and factors regarding the scope, degree and direction of cross-national policy convergence. Starting from a review of the theoretical literature on convergence and related concepts, we developed theoretical expectations on the main causal mechanisms suggested by these theories. From these considerations several general conclusions can be drawn.

First, our analysis shows that one should not expect a general increase in cross-national policy convergence - not even in the era of globalization. This is valid not only for the overall picture of the causes of policy convergence, but also for the individual causal mechanisms. Even if the mechanisms have an effect on policy convergence, it is - as a result of their differences in the 
Table 4 Theoretical expectations on scope, degree and direction of convergence

\begin{tabular}{|c|c|c|c|}
\hline Mechanism & $\begin{array}{l}\text { Factors affecting } \\
\text { convergence scope }\end{array}$ & $\begin{array}{l}\text { Factors affecting } \\
\text { convergence degree }\end{array}$ & $\begin{array}{c}\text { Expected } \\
\text { convergence direction }\end{array}$ \\
\hline Imposition & $\begin{array}{l}\text { Reach of the imposing } \\
\text { actor (individual } \\
\text { country vs. international } \\
\text { institution) }\end{array}$ & $\begin{array}{l}\text { (by definition full } \\
\text { convergence to } \\
\text { imposed model) }\end{array}$ & No prediction possible \\
\hline International harmonization & $\begin{array}{l}\text { Number of member } \\
\text { countries }\end{array}$ & $\begin{array}{l}\text { Degree of legal } \\
\text { specification } \\
\text { Capacity to } \\
\text { enforce compliance }\end{array}$ & $\begin{array}{l}\text { Upward shift for minimum } \\
\text { harmonization } \\
\text { Persistence for total } \\
\text { harmonization }\end{array}$ \\
\hline Regulatory competition & $\begin{array}{l}\text { Market economy } \\
\text { Trade-related policies }\end{array}$ & Trade dependence & $\begin{array}{l}\text { Upward or downward shift } \\
\text { for product standards } \\
\text { Downward shift for } \\
\text { process standards }\end{array}$ \\
\hline Transnational communication & $\begin{array}{l}\text { Apart from information } \\
\text { about policy choices } \\
\text { of other countries no } \\
\text { particular restrictions } \\
\text { apply }\end{array}$ & $\begin{array}{l}\text { Degree of existing } \\
\text { similarity (number } \\
\text { of adopters) } \\
\text { Cultural linkages } \\
\text { Degree of model } \\
\text { specification } \\
\text { Similarity of } \\
\text { policy legacies } \\
\text { Degree of inter-linkage } \\
\text { into transnational } \\
\text { networks }\end{array}$ & $\begin{array}{l}\text { Upward shift in case } \\
\text { of policy promotion } \\
\text { For other mechanisms } \\
\text { no prediction possible }\end{array}$ \\
\hline Independent problem-solving & $\begin{array}{l}\text { Number of countries that } \\
\text { recognize similar problem }\end{array}$ & $\begin{array}{l}\text { Degree of existing similarity } \\
\text { across countries }\end{array}$ & No prediction possible \\
\hline
\end{tabular}


scope of convergence - by no means justified to expect global convergence over all countries, policy areas and policy dimensions. As summarized in Table 4, the conditions and effects of convergence vary strongly across the different convergence mechanisms.

Second, and also apparent from Table 4, there is no clear picture at which level of regulation we can expect policy convergence. While some of the mechanisms might lead to an upward or downward shift of the average policy, for others no prediction is possible. In view of these findings, it is therefore hardly surprising that empirical findings on policy convergence and on races to the top or bottom are rather ambiguous.

Finally, this differentiated pattern of expectations about policy convergence was developed on the basis of the isolated analysis of each potential mechanism of convergence. Empirically, however, the mechanisms interact. It is thus an important area of future research to develop hypotheses and to undertake empirical research on the interaction effects of all potential causal mechanisms.

Addresses for correspondence: Katharina Holzinger, Institute of Political Science, University of Hamburg, Allendeplatz 1, D-20146 Hamburg, Germany. Tel: 494042838 4693. Fax: 494042838 3534. email: holzinger@ sozialwiss.uni-hamburg.de/Christoph Knill, Department of Politics and Management, University of Konstanz, Box D 81, D-78457 Konstanz, Germany. Tel: 497531 883553. Fax: 497531 882381. email: christoph.knill@ uni-konstanz.de

\section{ACKNOWLEDGEMENTS}

This article is based on the research project 'Environmental governance in Europe: the impact of international institutions and trade on policy convergence (ENVIPOLCON)'. We would like to thank the EU for providing funding for this project. For constructive criticism and helpful comments on earlier versions of this paper we are particularly grateful to Bas Arts, Fabrizio Gilardi, Helge Jörgens and Andrea Lenschow as well as the participants of the Hamburg Workshop on 'International Sources of Policy Convergence', held in April 2004.

\section{NOTE}

1 As convergence can primarily be expected if legal obligation requires the harmonization of national regulations, we will not consider regulatory options that offer more leeway for member states (e.g. mutual recognition), hence potentially leading to diverging rather than converging outputs in the member states.

\section{REFERENCES}

Andersen, M.S. and Liefferink, D. (1997) European Environmental Policy. The Pioneers, Manchester: Manchester University Press. 
Baum, J.A.C. and Oliver, C. (1992) 'Institutional embeddedness and the dynamics of organizational populations', American Sociological Review 7: 540-59.

Bennett, C. (1988) 'Different processes, one result. The convergence of data protection policy in Europe and the United States', Governance 1: 162-83.

Bennett, C. (1991) 'What is policy convergence and what causes it?', British Journal of Political Science 21: 215-33.

Botcheva, L. and Martin, L.L. (2001) 'Institutional effects on state behaviour. Convergence and divergence', International Studies Quarterly 45: 1-26.

DiMaggio, P.J. and Powell, W.W. (1991) 'The iron cage revisited. Institutionalized isomorphism and collective rationality in organizational fields', in W.W. Powell and P.J. DiMaggio (eds), The New Institutionalism in Organizational Analysis, Chicago: Chicago University Press, pp. 63-82.

Dolowitz, D.P. and Marsh, D. (1996) 'Who learns what from whom? A review of the policy transfer literature', Political Studies 44: 343-57.

Dolowitz, D.P. and Marsh, D. (2000) 'Learning from abroad: the role of policy transfer in contemporary policy making', Governance 13: 5-24.

Drezner, D.W. (2001) 'Globalization and policy convergence', The International Studies Review 3: 53-78.

Finnemore, M. (1996) National Interests in International Society, Ithaca, NY: Cornell University Press.

Friedkin, N.E. (1993) 'Structural bases of interpersonal influence in groups. A longitudinal case study', American Sociological Review 58: 61-872.

Gilardi, F. (2005) 'The international foundations of regulatory capitalism: the diffusion of independent regulatory agencies in Western Europe', The Annals of the American Academy of Political and Social Science 598: 84-101.

Gilardi, F. and Braun, D. (2005) 'Taking "Galton's problem” seriously: towards a theory of policy diffusion'. Paper presented at the Convention of the International Studies Association, March 2005, Honolulu.

Guler, I., Guillén, M. and Macpherson, J. (2002) 'Global competition, institutions and the diffusion of organizational practices. The international spread of ISO 9000 quality certificates', Administrative Science Quarterly 47: 207-33.

Haas, P.M. (1992) 'Introduction: Epistemic communities and international policy coordination', International Organization 46: 1-36.

Heichel, S., Pape, J. and Sommerer, T. (2005) 'Is there convergence in convergence research? An overview of empirical studies on policy convergence', Journal of European Public Policy 12(5): 817-40.

Héritier, A., Knill, C. and Mingers, S. (1996) Ringing the Changes in Europe. Regulatory Competition and the Transformation of the State, Berlin: de Gruyter.

Hoberg, G. (2001) 'Globalization and policy convergence: symposium overview', Journal of Comparative Policy Analysis: Research and Practice 3: 127-32.

Holzinger, K. (1994) Politik des kleinsten gemeinsamen Nenners. Umweltpolitische Entscheidungsprozesse in der EG am Beispiel des Katalysatorautos, Berlin: Edition Sigma.

Holzinger, K. (2002) 'The provision of transnational common goods: regulatory competition for environmental standards', in A. Héritier (ed.), Common Goods: Reinventing European and International Governance, Lanham: Rowman \& Littlefield, pp. 59-82.

Holzinger, K. (2003) 'Common goods, matrix games, and institutional solutions', European Journal of International Relations 9: 173-212.

Holzinger, K. and Knill, C. (2005) 'Competition, cooperation and communication. A theoretical analysis of different sources of environmental policy convergence and their interaction', Working Paper, Political Science Series 102, Vienna: Institute for Advanced Studies. 
Humphreys, P. (2002) 'Europeanisation, globalisation and telecommunications governance: a neo-Gramscian analysis', Convergence: The Journal of Research into New Media Technologies 8: 52-79.

Jänicke, M. (1998) 'Umweltpolitik. Global am Ende oder am Ende global?', in U. Beck (ed.), Perspektiven der Weltgesellschaft, Frankfurt a. Main: Suhrkamp, pp. 332-44.

Keck, M.E. and Sikkink, K. (1998) Articles beyond Borders. Networks in International Politics, Ithaca, NY: Cornell University Press.

Kern, K. (2000) Die Diffusion von Politikinnovationen. Umweltpolitische Innovationen im Mehrebenensystem der USA, Opladen: Leske + Budrich.

Kern, K., Jörgens, H. and Jänicke, M. (2000) 'Die Diffusion umweltpolitischer Innovationen. Ein Beitrag zur Globalisierung von Umweltpolitik', Zeitschrift für Umweltpolitik 23: 507-46.

Knill, C. (2001) The Europeanisation of National Administrations, Cambridge: Cambridge University Press.

Knill, C. (2005) 'Introduction: Cross-national policy convergence: concepts, approaches and explanatory factors', Journal of European Public Policy 12(5): 764-74.

Levi-Faur, D. (2002) 'Herding towards a new convention. On herds, shepherds and lost sheep in the liberalization of the telecommunications and electricity industries'. Paper presented at the workshop 'Theories of Regulation', Nuffield College, University of Oxford.

Martin, L. and Simmons, B. (1998) 'Theories and empirical studies of international institutions', International Organization 52: 729-57.

Meseguer Yebra, C. (2003) 'Learning and economic policy choices: a Bayesian approach', EUI Working Paper RSC No. 2003/5, San Domenico: European University Institute.

Meyer, J.W. and Rowan, B. (1977) 'Institutionalized organizations. Formal structure as myth and ceremony', American Journal of Sociology 83: 340-63.

Meyer, J.W., Frank, D.J., Hironaka, A., Schofer, E. and Brandon-Tuma, N. (1997) 'The structuring of a world environmental regime, 1870-1990', International Organization 51: 623-51.

Rose, R. (1991) 'What is lesson-drawing?', Journal of Public Policy 11: 3-30.

Scharpf, F.W. (1997) 'Introduction: the problem-solving capacity of multi-level governance', Journal of European Public Policy 4: 520-38.

Seeliger, R. (1996) 'Conceptualizing and researching policy convergence', Policy Studies Journal 4: 287-306.

Simmons, B.A. and Elkins, Z. (2004) 'The globalization of liberalization: policy diffusion in the international political economy', American Political Science Review 98: $171-89$.

Strang, D. and Meyer, J. (1993) 'Institutional conditions for diffusion', Theory and Society 22: 487-511.

Tews, K. (2002) 'Politiktransfer: Phänomen zwischen Policy-Lernen und Oktroi. Überlegungen zu unfreiwilligen Umweltpolitikimporten am Beispiel der EUOsterweiterung', Zeitschrift für Umweltpolitik und Umweltrecht 2: 173-201.

Tsebelis, G. (2002) Veto Players. How Political Institutions Work, Princeton, NJ: Princeton University Press.

Vogel, D. (1995) Trading Up. Consumer and Environmental Regulation in the Global Economy, Cambridge, MA: Harvard University Press.

Wallace, D. (1995) Environmental Policy and Industrial Innovation. Strategies in Europe, the US and Japan, London: Earthscan. 